https://doi.org/10.17816/MAJ191S1172-174

\title{
PROBABLE ANALGESIC EFFECT OF SYNTHETIC TETRAPEPTIDE
}

\author{
V.B. Plakhova, V.A. Penniyaynen, I.V. Rogachevskii, S.A. Podzorova, E.A. Merculova, B.V. Krylov
}

Pavlov Institute of Physiology of the Russian Academy of Sciences, Saint Petersburg, Russia

\section{ВОЗМОЖНОЕ АНАЛЬГЕТИЧЕСКОЕ ДЕЙСТВИЕ СИНТЕТИЧЕСКОГО ТЕТРАПЕПТИДА}

\author{
В.Б. Плахова, В.А. Пеннияйнен, И.В. Рогачевский, С.А. Подзорова, Е.А. Меркулова, Б.В. Крылов \\ ФГБУН «Институт физиологии им. И.П. Павлова» РАН, Санкт-Петербург
}

The aim of the study was to elucidate the molecular mechanisms of modulation of the $\mathrm{Na}_{\mathrm{v}} 1.8$ channels with a synthetic tetrapeptide (Ac- $\mathrm{RERR}-\mathrm{NH}_{2}$ ). Our data suggest that this substance specifically modulates the activation gating device of these channels, which are responsible for coding of pain signals. This agent $(0.1 \mathrm{nM})$ has a neurite-stimulating effect, which indicates its possible physiological regeneration effect on the nervous tissue. The results obtained allow us to conclude that the agent under study can claim to be the drug substance of a safe and effective analgesic.

Keywords: $\mathrm{Na}_{\mathrm{v}} 1.8$ channels; neurite growth; nociception.

Целью исследования явилось выяснение молекулярных механизмов модуляции каналов $\mathrm{Na}_{\mathrm{v}} 1.8$ синтетическим тетрапептидом (Ac- RERR- $\mathrm{NH}_{2}$ ). Наши данные свидетельствуют о том, что указанная субстанция специфически влияет на активационное воротное устройство этих каналов, ответственных за кодирование болевых сигналов. Этот агент в концентрации 0,1 нмоль/л обладает нейрит-стимулирующим эффектом, что указывает на его возможное физиологическое регенерационное действие в отношении нервной ткани. Полученные результаты позволяют заключить, что исследуемый агент может претендовать на роль лекарственной субстанции безопасного и эффективного анальгетика.

Ключевые слова: каналы $\mathrm{Na}_{\mathrm{v}} 1.8$; рост нейритов; ноцицепция.

Introduction. Endogenous antibiotics defensins are produced by the epithelial cells and also by lymphocytes, keratinocytes and phagocytic cells, etc. We have found their additional antinociceptive effect due to their action on the activation gating system of the $\mathrm{Na}_{\mathrm{v}} 1.8$ channels [1]. The goal of our study is to find the shortest amino acid sequence as a fragment of the defensin structure, which has strong analgesic properties that can be comparable to the effectiveness of defensins in their ability to reduce the voltage-sensitivity of $\mathrm{Na}_{\mathrm{v}} 1.8$ channels. We have developed a hypothesis that the specific decrease in the voltage-sensitivity of these channels allows the polymodal nociceptors to retain the ability to transmit signals of other modalities, selectively turning off the high-frequency component of their impulse activity that carries to CNS nociceptive information [2]. This article shows that the tetrapeptide (Ac-RERR- $\mathrm{NH}_{2}$ ) which is consistent with the structure of defensin (NP-1 or NP-4), has strong antinociceptive effect.

Material and methods. Experiments were performed on cultured sensory neurons isolated from the regions of L5-S1 dorsal root ganglia (DRG) of newborn Wistar rats using the standard solutions Ionic currents were registered using wholecell patch-clamp method [1]. The DRG organotypic culture was obtained from a chicken embryo according to the standard procedure described in detail in our previous work [3]. The synthetic tetrapeptide Ac-RERR-NH2 purity was characterized by analytical HPLC (purity > 95\%) and mass spectrometry. The new born rats were obtained from the Biocollection of Pavlov Institute of Physiology. Experiments were conducted using the equipment of the Confocal Microscopy Collective Use Center at Pavlov Institute of Physiology RAS.

The data were analyzed with STATISTICA 10.0 package and expressed as the mean value \pm standard error of the mean. Statistical significance was set at $p<0.05$.

Results and discussion. $\mathrm{Na}_{\mathrm{V}} 1.8$ currents were recorded under control conditions and after exposure Ac-RERR- $\mathrm{NH}_{2}$ at a concentration of $100 \mathrm{nM}$. The process of ligand-receptor binding of the attacking molecule with a $\mathrm{Na}_{\mathrm{V}} 1.8$ channel leads to a change in the value of the effective charge $\left(Z_{\text {eff }}\right)$ transfer of the activation gate device of this channel. To quantify $Z_{\text {eff }}$ we used the modified Almers' method [2]. We have found the values of changes in the effective charge in the control experiments and after the application of tetrapeptide at a concentration of $100 \mathrm{nM}$ : $Z_{\text {eff }}=6.4 \pm 0.3(n=17$, control data $)$, and $4.6 \pm 0.3$ $(n=23$, after tetrapeptide application). The results indicate that the agent has a strong effect on the activation gating device of $\mathrm{Na}_{\mathrm{V}} 1.8$ sodium channels. This makes Ac-RERR- $\mathrm{NH}_{2}$ a very promising contender for the role of an analgesic drug substance. 
The effects of Ac-RERR- $\mathrm{NH}_{2}$ (concentrations from $1 \mathrm{pM}$ to $100 \mathrm{nM}$ ) on the neurites growth of DRG neurons of chicken embryos were studied. At concentrations of $0.1 \mathrm{pM}$ and $10 \mathrm{pM}$, tetrapeptide had no effect on the neurite growth of the tissue under study: the area index (AI) of the explants did not differ from the control value. At a concentration of $0.1 \mathrm{nM}$ tetrapeptide showed neuritisstimulating effect: its application caused significant stimulation of neurite growth by an average of $34 \%$. When tetrapeptide was added to the culture medium at higher concentrations unreliable stimulation or little effect on the growth of DRG neuritis were registered. The data obtained indicate that AcRERR- $\mathrm{NH}_{2}$ has pronounced neurite- stimulating properties at a very low concentration $(0.1 \mathrm{nM})$.

We emphasize that a strong influence on the gating device of $\mathrm{Na}_{\mathrm{v}} 1.8$ channels and the stimulating effect on nerve tissue confirms the prospects of further studies of this agent (AcRERR-NH $\mathrm{NH}_{2}$ ) as a candidate for the role of an analgesic substance drug which is capable of safely and effectively relieving neuropathic pain.

Acknowledgments. The present work was funded by the Russian Foundation for Basic Research, project No. 18-015-00079. The studies were financially supported by the Program of Fundamental Scientific Research in State Academies for 2014-2020 (SP-14, section 64).

\section{References}

1. Plakhova VB, Rogachevskii IV, Shchegolev BF, et al. Defensin NP-4 decreases voltage-sensitivity of slow sodium channels in sensory neuron. Sensornye Sistemy. 2005;19(2):110-116. (In Russ.).

2. Krylov, BV, Rogachevskii IV, Shelykh TN, Plakhova VB. New non-opioid analgesics: understanding molecular mechanisms on the basis of patch-clamp and quantum-chemical studies. Frontiers in pain sci. Sharjah: Bentham Sci. Publ. 2017;1:203.

3. Penniyaynen VA, Plakhova VB, Rogachevskii IV, Krylov BV. Src kinase is involved in comenic acidtriggered signaling pathways in sensory neurons. Activitas nerv. super. Rediviva. 2018;60(1):19-27. 